\title{
Formation and Thermal Behavior of Metal Hydroxide- Intercalated Tantalum Disulfide
}

\author{
Yoshiaki SAITo,* Masaaki MAKINO,* NoboruYAMAZOE* and Tetsuro SeIYAMA*
}

Formation and thermal behavior of metal hydroxide intercalated tantalum disulfide were studied. Intercalation of hydroxides into $\beta-\mathrm{TaS}_{2}$ resulted in the expansion of layer spacing by $5.8 \AA$ (type I ) or by $2.9 \AA$ (type II), the intercalation of $\mathrm{NaOH}$ and $\mathrm{Ca}(\mathrm{OH})_{2}$ gave the former type, while that of $\mathrm{LiOH}, \mathrm{KOH}$ and $\mathrm{Ba}(\mathrm{OH})_{2}$ gave the latter. It was found that the expansion was controlled by the amounts of water incorporated together with the guest hydroxides. On dehydration by evacuation or heating, the layer spacing became narrower consecutively to form three new types, III, IV and V, the layer spacings of which were larger by $1.5,0.8$ and $0.3 \AA$ han that in $\beta-\mathrm{TaS}_{2}$, respectively. It was deduced that all these five types were related with each other in a characteristic manner which was best accounted for by assuming stage compounds.

\section{Introduction}

Tantalum disulfide has a layer structure') in which layers of $\mathrm{TaS}_{2}$ composition are stacked one by one with van der Waals force. It is known that many bases and Lewis bases such as $\mathrm{NaOH}$, pyridine etc. can be easily intercalated into the layer spacings to form a group of so called intercalation compounds ${ }^{2,3)}$. Extensive studies for the intercalation compoundes have been made on the physical properties such as super conductivity ${ }^{4,5)}$. The chemical properties of them, however, have not been studied satisfactorily. For example, it has been suspected that, when metal hydroxide is intercalated, considerable amounts of water molecules also get into the layer spacings ${ }^{67}$, but no thorough investigation has been made on it. There is no investigation on the thermal properties of the intercalation compounds either. In this report, we have studied the intercalation of hydroxides of alkali or alkaline earth metals into $\mathrm{TaS}_{2}$. Particular attention has been focused upon the thermal behavior of the intercalation compounds as well as upon the relationship between intercalated water and crystal structure.

\section{Experimental}

Pure phase of $\alpha$ tantalum disulfide $\left(\alpha-\mathrm{TaS}_{2}\right)$

* Department of Materials Science and Technology, Graduate School of Engineering Science, Kyushu University (6-1, Kasugakouen, Kasuga 816)

Key Words : Intercalation Compound, Tantalum Disulfide, Layer Structure was prepared by heating tantalum powder with sulfur vapor at about $900^{\circ} \mathrm{C}$ in a sealed quartz tube as described elsewhere ${ }^{i)}$. To obtain $\beta$ $\mathrm{TaS}_{2}, \alpha-\mathrm{TaS}_{2}$ was ground to powder and, after the addition of a small amount of iodine, annealed at $600^{\circ} \mathrm{C}$ for 4 days and then at 500 ${ }^{\circ} \mathrm{C}$ for 2 weeks. Aqueous solutions of metal hydroxide were prepared with $\mathrm{CO}_{2}$ free water and standardized before use.

The intercalation reaction was performed by suspending $\mathrm{TaS}_{2}$ in the hydroxide solution under vigorous stirring. After the reaction, the suspension was filtered and the residue (Product) was washed repeatedly with deionized water before storage in a desicator. The amount of intercalated hydroxide was determined by the neutralization analysis of the filtrate. The intercalation product was identified by X-ray powder diffraction (Rigaku-Denki, D-3F) with $\mathrm{CuK}_{\alpha}$ radiation. The sorption or desorption of water was measured gravimetrically with a silica balance. The thermal behavior was pursued either on an X-ray diffractometer attached with a high temperature apparatus, or by differential thermal analysis (DTA).

\section{Results}

\subsection{Intercalation of metal hydroxides}

An example of the intercalation reaction of $\mathrm{NaOH}$ into $\beta-\mathrm{TaS}_{2}$ is shown in Fig. 1, where $p$ denotes the molar ratio of the intercalated hydroxide to $\beta-\mathrm{TaS}_{2}$. The reaction was rather rapid. Although an increase in reaction time increased the $p$ value gradually, it also resulted 


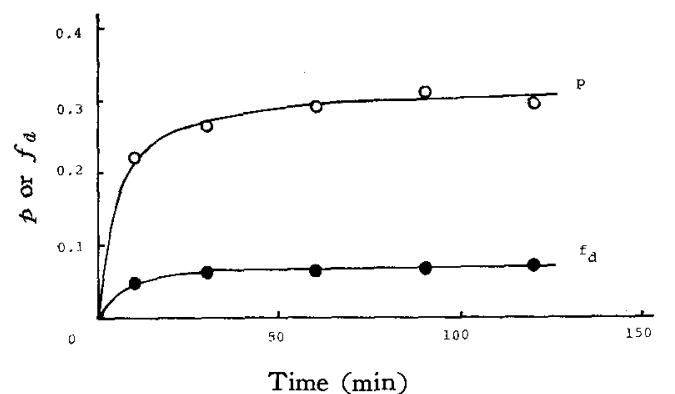

Fig. 1 Intercalation of $\mathrm{NaOH}$ into $\mathrm{TaS}_{2}\left(22^{\circ} \mathrm{C}\right)$ $p:$ Molar ratio of intercalated $\mathrm{NaOH}$ to $\beta-\mathrm{TaS}_{2}\left(\mathrm{TaS}_{2}\right.$ - $p \mathrm{NaOH}), f_{a}$ : Fraction of decomposed $\mathrm{TaS}_{\mathrm{z}}$

in the decomposition of a part of $\mathrm{TaS}_{2}$ to liberate free sulfide ions. The liberated sulfide ions were analyzed by iodometry and their fractions to total sulfur, $f_{d}$, are also shown in the same figure. The decomposition of $\mathrm{TaS}_{2}$ was reduced either by decreasing the concentration of $\mathrm{NaOH}$ solution or by lowering the reaction temperature, but it was hardly prevented completely. Because of such decomposition the intercalation reaction was usually discontinued at $1.5 \mathrm{hr}$. The $p$ value depended upon the reaction conditions, ranging from 0.18 to 0.33 .

In this way, $\beta-\mathrm{TaS}_{2}$ was intercalated with $\mathrm{LiOH}, \mathrm{NaOH}, \mathrm{KOH}, \mathrm{Ca}(\mathrm{OH})_{2}$ and $\mathrm{Ba}(\mathrm{OH})_{2}$. Typical X-ray diffraction patterns of $\beta-\mathrm{TaS}_{2}$ and intercalation compounds are shown in Fig. 2. Intercalation caused significant expansion in layer spacing of the host structure as visualized by the lowering of diffraction angles (2 $\theta)$ for $(00 l)$ line. The observed hexagonal lattice parameters, a and $c$, of the intercalation compounds are listed in Table 1, which were in good agreement with those reported by Subba Rao et $a l .{ }^{6}$. It is remarkable that the expansion in layer spacing $(\triangle c / 2)$, falls in the range of either $5.74 \sim 5.91 \AA$ (type I) or $2.92 \sim 2.99 \AA$ (type $I I$ ), depending upon the hydroxide intercalate. The expansion of type I was usually observed for the intercalation compound of $\mathrm{NaOH}$ or $\mathrm{Ca}(\mathrm{OH})_{2}$, while intercalation of $\mathrm{LiOH}, \mathrm{KOH}$, or $\mathrm{Ba}(\mathrm{OH})_{2}$ belonged to type II (Table 1 and Fig. 1). In some cases, however, the expansion was dependent on the conditions of intercalation. In the case of $\mathrm{LiOH}$-intercalated compounds, for instance, preparation at room temperature gave type $\Pi$, while a mixture of types $\mathrm{I}$ and $\Pi$ was obtained at $60^{\circ} \mathrm{C}$.
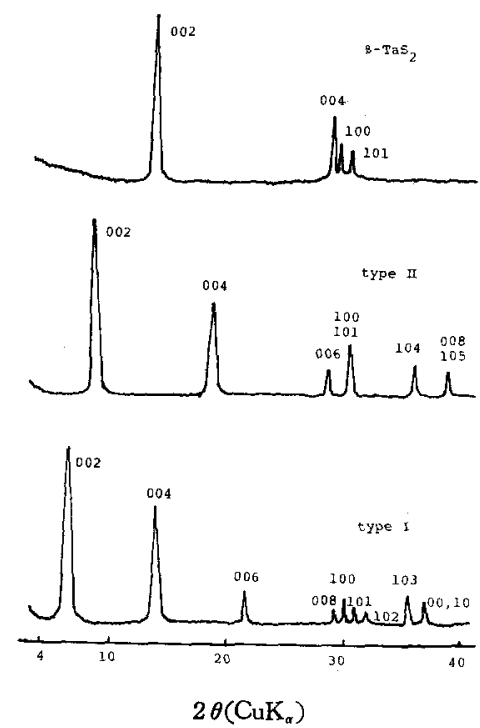

Fig. 2 X-ray powder diffraction patterns of $\beta-\mathrm{TaS}_{2}$ and ntercalation products

Type I : $\mathrm{NaOH}$ or $\mathrm{Ca}(\mathrm{OH})_{2}$ intercalated $\mathrm{TaS}_{2}$, Type II : $\mathrm{LiOH}, \mathrm{KOH}$, or $\mathrm{Ba}\left(\mathrm{OH}_{2}\right)$ intercalated $\mathrm{TaS}_{2}$

Table 1 Lattice constants of intercalation products

\begin{tabular}{l|c|c|c|c}
\hline \multirow{2}{*}{$\begin{array}{c}\text { Guest } \\
\text { hydroxide }\end{array}$} & \multicolumn{4}{|c}{ Lattice constants } \\
\cline { 2 - 5 } $\mathrm{L}(\AA)$ & $\mathrm{c}(\AA)$ & \multicolumn{1}{c}{$c / 2(\AA)$} & Type \\
$\mathrm{LiOH}$ & 3.33 & $2 \times 8.99$ & 2.94 & II \\
$\mathrm{NaOH}$ & 3.31 & $2 \times 11.96$ & 5.91 & $\mathrm{I}$ \\
$\mathrm{KOH}$ & 3.32 & $2 \times 9.04$ & 2.99 & II \\
$\mathrm{Ca}(\mathrm{OH})_{2}$ & 3.31 & $2 \times 11.79$ & 5.74 & I \\
$\mathrm{Ba}(\mathrm{OH})_{2}$ & 3.30 & $2 \times 8.97$ & 2.92 & II \\
\hline host $\beta-\mathrm{TaS}_{2}$ & 3.32 & $2 \times 6.05$ & & \\
\hline
\end{tabular}

As stated above, $\beta-\mathrm{TaS}_{2}$ easily reacted with alkali or alkaline earth hydroxides giving two types of intercalation compounds. Unlike $\beta$ $\mathrm{TaS}_{2}$, however, $\alpha-\mathrm{TaS}_{2}$ was found to be quite inactive at room temperature, showing that the reaction is structure-sensitive. Even after a suspension of $\boldsymbol{\alpha}-\mathrm{TaS}_{2}$ in $\mathrm{NaOH}$ solution was heated to $160^{\circ} \mathrm{C}$ for $24 \mathrm{hr}$ in a sealed quartz tube, a major part of $\alpha-\mathrm{TaS}_{2}$ remained unchang. ed, with the rest having been converted into a mixture of types $I$ and II.

\subsection{Sorption of water}

As mentioned above, the intercalation compounds have largely expanded layer spacings. To account for the large expansion, Subba Rao et $a{ }^{6}{ }^{6)}$ have proposed that the guest ions enter the layer spacing together with the water 


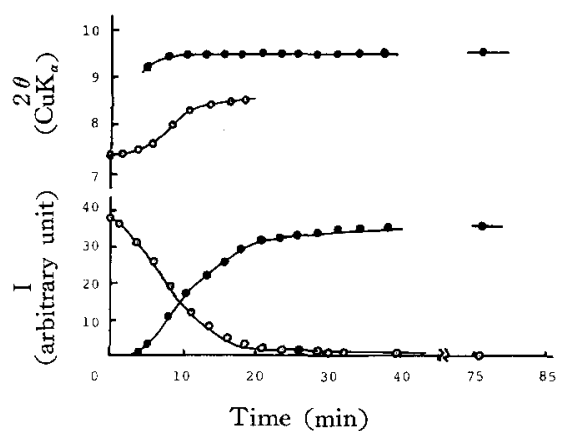

Fig. 3 I-type $\rightarrow$ II-type transition of $\mathrm{TaS}_{2}(\mathrm{NaOH})_{x}\left(\mathrm{H}_{2} \mathrm{O}\right)_{y}$ by evacuation $\mathrm{O}:(002)_{\mathrm{I}}, \mathrm{O}:(002)_{\mathrm{II}}$

of hydration, and attempted to relate the large expansion in terms of the radii of hydrated ions. However, they neither measured the actual content of water, nor paid attention to the fact that the expansion can not vary continuously but is classified into two types. In this section, we examined the sorption of water in relation to the layer expansion.

It was found that the $\mathrm{NaOH}$-intercalated compound, $\mathrm{TaS}_{2}(\mathrm{NaOH})_{x}$, which was prepared as type I structure, was converted into type II on evacuation at room temperature. Figure 3 shows the changes in $\mathrm{X}$-ray diffraction intensity and diffraction angle for (002) lines. The diffraction angle $(2 \theta)$ of type I structure was observed to increase a little in the initial stages, showing that the layer spacing of type I shrinks somewhat before the conversion. It is to be noted, however, that despite such preliminary phenomena the change of layer spacing from type I to II is essentially discontinuous.

The conversion $\mathrm{I} \rightarrow \mathrm{II}$ mentioned above is

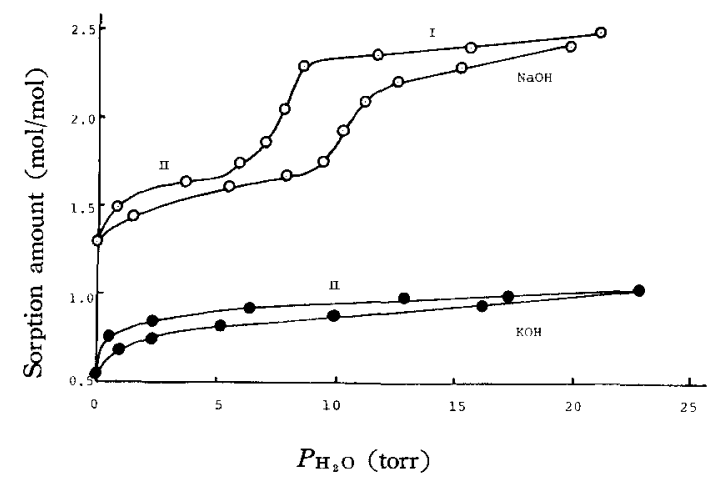

Fig. 4 Sorption isotherms for $\mathrm{TaS}_{2}-\mathrm{MOH}$ complex at $25^{\circ} \mathrm{C}$ likely associated with the decrease of water content of the sample. To confirm this, the sorption isotherms of water vapor were measured gravimetrically at $25^{\circ} \mathrm{C}$ for $\mathrm{TaS}_{2}(\mathrm{NaOH})_{x}$. As shown in Fig. 4, the isotherm distinctly shown an inflection at water vapor pressure $\left(P_{\mathrm{H}_{2} \mathrm{O}}\right)$ of 8 10 Torr, though there were considerable hysteresis effects. The inflection of the isotherm indicates the occurrence of a phase transition, which was identified to be I (higher $P_{\mathrm{H}_{2} \mathrm{O}}$ ) $\rightleftarrows$ II (lower $P_{\mathrm{H}_{2} \mathrm{O}}$ ) by X-ray diffraction analysis. The KOH-intercalated sample, which was prepared in type $I$, showed no such inflection at room temperature as shown in the same figure. These facts indicate that the layer spacings are largely dependent upon the water content. It is also noted that type II still contains considerable amounts of water at $25^{\circ} \mathrm{C}$.

\subsection{Thermal behavior of intercalation compounds}

The structural change of intercalation compounds was studied by heating the samples in a high temperature apparatus attached to the $\mathrm{X}$ ray diffractometer. The $\mathrm{X}$-ray diffraction patterns for $\mathrm{TaS}_{2}(\mathrm{NaOH})_{x}$ are shown in Fig. 5. This compound exhibited $I \rightarrow I I$ conversion

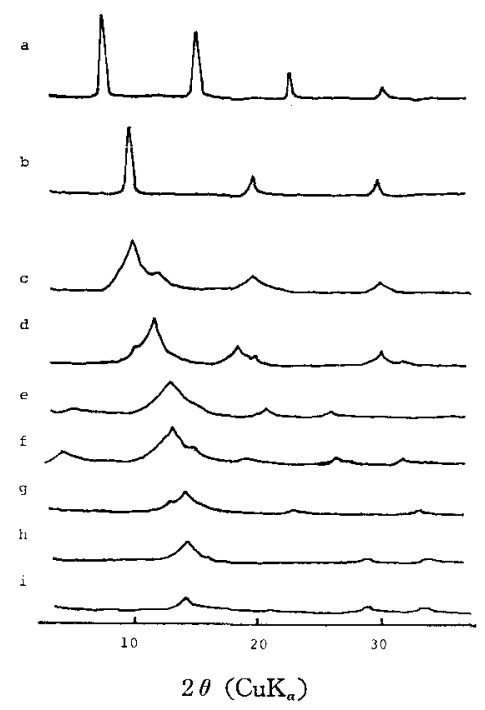

Fig. 5 Structural change of $\mathrm{NaOH}$ intercalation compound with heating in the high temperature camera

a : R.T. (type I ), b:R.T. (after evac.) (type II), $\mathrm{c}: 50^{\circ} \mathrm{C}, \mathrm{d}: 110^{\circ} \mathrm{C}$ (type III), e $: 130^{\circ} \mathrm{C}$ (type $\mathrm{N}$ ), $\mathrm{f}: 160^{\circ} \mathrm{C}, \mathrm{g}: 190^{\circ} \mathrm{C}$ (type $\mathrm{V}$ ), $\mathrm{b}:$ $240^{\circ} \mathrm{C}$, i : $500^{\circ} \mathrm{C}$ 
by evacuation at room temperature as stated before. The subsequent heating was carried out in vacuo. With a rise in temperature up to $500^{\circ} \mathrm{C}$, there appeared three phases stepwise as evidenced by the changes of diffraction patterns. We name these phases III, IV and V respectively. The diffraction lines of these phases could be indexed by assuming layer structure. The layer spacings (c) shrinked stepwise as listed in Fig. 5, and the layer expansions $(\triangle c / 2)$ for phase $\mathbb{I I}, \mathrm{IV}$ and $\mathrm{V}$ are $1.5 \AA, 0.8 \AA$ and $0.3 \AA$ respectively.

The thermogravimetric (T.G.) analysis was carried out to determine how these phase transitions are related to the changes in water content of the samples. Figure 6 shows the T.G. curve for $\mathrm{NaOH}$ intercalated sample, together with the structural information obtained by the previous X-ray diffraction study. The $\mathrm{NaOH}$ intercalated compound showed steep weight losses at about $40^{\circ} \mathrm{C}$ and $120^{\circ} \mathrm{C}$, which corresponded to $\mathrm{I} \rightarrow \mathrm{II}$ and $\mathrm{III} \rightarrow \mathrm{IV}$ transitions respectively. The weight decreased gradually up to $500^{\circ} \mathrm{C}$, while the transition to the final type $\mathrm{V}$ went to completion at $240^{\circ} \mathrm{C}$ (see Fig. $5)$. The water content per mole of $\mathrm{TaS}_{2}, \mathrm{Y}$, was determined on the basis of the dry weight at $500^{\circ} \mathrm{C}$. It is thus seen that the lowest temperature phase, type $\mathrm{I}$, contains more than 2 water molecules per $\mathrm{TaS}_{2}$; the water content decreases with increasing temperature accompanied several phase transitions. The $\mathrm{KOH}$ intercalated compound exhibited a similar weight loss at about $100^{\circ} \mathrm{C}$ in vacuo, which was found to correspond to $\mathrm{II} \rightarrow \mathrm{III}$ conversion from $\mathrm{X}$ ray diffraction study. In this case, however, heating above $150^{\circ} \mathrm{C}$ was not attempted.

\subsection{Structure of interealation compounds}

As was stated in the foregoing sections, about $0.3 \mathrm{~mol}$ of hydroxides could be intercalated in $\mathrm{TaS}_{2}$, irrespective of the kind of hydroxides. The intercalation compounds thus formed were classified into two types, I and II, which had different layer spacings. On evacuation at room temperature, type I transformed into II, which on thermal dehydration was further converted stepwise into $\mathrm{II}, \mathrm{IV}$ and $\mathrm{V}$, the types of narrower layer spacings. It appears that the layer spacing is not associated directly with the kind of guest hydroxide but determined by the amount of water introduced together. Figure 7 shows the increment of layer spacing, $\triangle c / 2$, of each type of $\mathrm{NaOH}$-intercalation compounds relative to that of pure $\beta-\mathrm{TaS}_{2}$ as a function of the water content. Obviously $\triangle c / 2$ increases almost in proportion to the water content except for type $\mathrm{V}$, confirming the above estimation.

In what manner are such water molecules incorporated in the intercalation compounds? In connection with this question, Subba et al. have proposed that water is incorporated as the water of hydration of the guest ions. This proposal, however, encounters two difficulties. First, since the hydration number should depend on ionic species, the layer spacing should also depend on the guest hydroxides. In practice, however, any intercalation compound prepared in aqueous hydroxide solutions belongs to either type I or II, irrespective of the hydroxide used. Second, it is expected that dehydration from hydrated ions should proceed continuously on heating, and therefore, if the radii of hydrated ions determines the layer spacing, the layer spacing should shrink continuously on sample heating, in contrast to such abrupt changes of layer spacing as observed.

In this line of consideration, we propose that, while a part of the incoorporated water exists as the water of hydration of guest ions, a major part is used for filling space between layers determining the layer spacing. It is suspected that the latter is not arranged at random in the layer space but maintains a certain degree of order and behaves like the water of crystallization. We presume that the discontinuous change of the layer spacing during dehydration

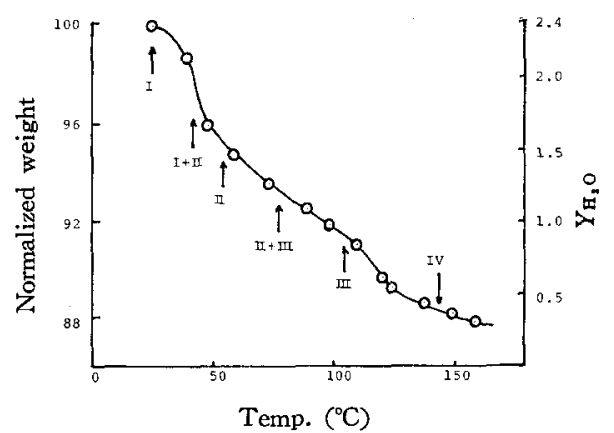

Fig. 6 TGA curve for $\mathrm{TaS}_{2}(\mathrm{NaOH})_{x}\left(\mathrm{H}_{2} \mathrm{O}\right)_{y}$ $P_{\mathrm{H}_{3} \mathrm{O}}=20$ torr, $Y=\left[\mathrm{H}_{2} \mathrm{O}\right] /\left[\mathrm{TaS}_{2}\right]$ 


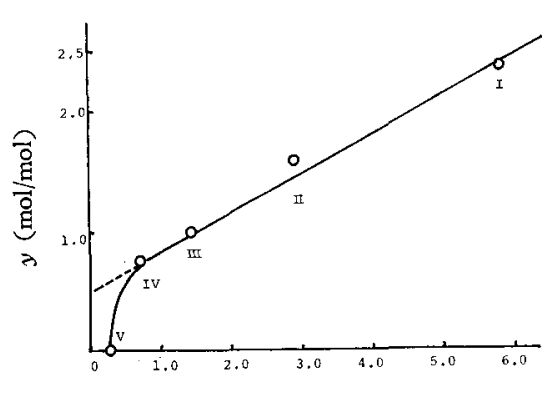

$\triangle c / 2(\AA)$

Fig. 7 Relation between water content (y) and increase in layer spacing $(\Delta c / 2)$ of $\mathrm{TaS}_{2}(\mathrm{NaOH})_{x}\left(\mathrm{H}_{2} \mathrm{O}\right)_{y}$ $y=\left[\mathrm{H}_{2} \mathrm{O}\right] /\left[\mathrm{TaS}_{2}\right]$

results from the reordering of the water of crystallization from one stable arrangement to another, just as seen for anusual crystalline hydrate.

From this point of view, suggestive is the correlation of Fig. 7 between $\triangle c / 2$ and water content. The straight line going through the points for type I through IV intersects $Y$ axis at about $0.5 \mathrm{~mol} \mathrm{H}_{2} \mathrm{O}$ per mol $\mathrm{TaS}_{2}$. This amount of water is not effective for the expansion of layer spacing and therefore assignable as the water of hydration of the guest ions. The remaining water, on the other hand, can be assigned as the water of crystallization determining the layer spacing. The amount of this kind of water are about $2,1,0.5$ and 0.25 mol $-\mathrm{H}_{2} \mathrm{O}$ per $\mathrm{TaS}_{2}$ for types $\mathrm{I}$ through $\mathrm{IV}$, respectively. It is noted that the amount is halved successing on going from a type to next. A corresponding change is observed in $\triangle c / 2$. That is, the $\Delta c / 2$ is $5.8,2.9,1.5$ and $0.8 \AA$ for types $\mathrm{I}$ through $\mathrm{IV}$, respectively, becoming almost halved on going from $I$ to $I I$, and so on. For type $V$, which is no longer hydrated, $\Delta c / 2$ is only about $0.3 \AA$. This shows that the dehydrated $\mathrm{Na}^{+}$ and $\mathrm{OH}^{-}$ions are located in the octahedral sites of $\mathrm{TaS}_{2}$, causing only a limited extent of layer expansion.

The relation between layer spacing and water content for type I through IV mentioned above seems to be understood most satisfactorily by assuming that each type represents a phase of so called stage compounds. The most wellknown example of stage compounds has been provided by graphite-alkali metal systems.

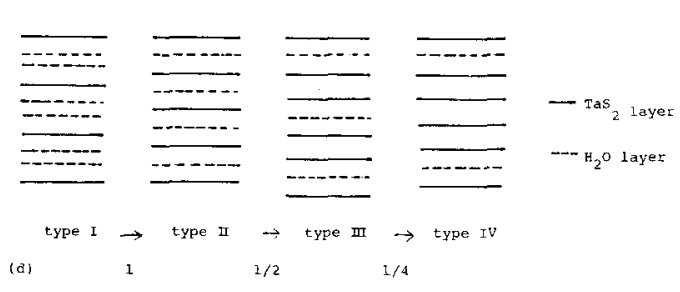

Fig. 8 Stage compounds model for $\mathrm{NaOH}-$ intercalation compounds

$\mathrm{d}$ : Desorption amount of $\mathrm{H}_{2} \mathrm{O}$ [layer] $/ \mathrm{TaS}_{2}$ [layer]

A model for the stage compounds in the present is proposed in Fig. 8. For simplicity the structure is considered to be constructed with two building units, one the $\mathrm{TaS}_{2}$ layer (shown by full lines) and the other the layer of the water of crystallization (shown by broken lines). The guest ions and its hydration water should be somewhere between the $\mathrm{TaS}_{2}$ layers but are neglected in the drawing because they exert relatively minor effects structurally. In the proposed model, double $\mathrm{H}_{2} \mathrm{O}$ layers and a single $\mathrm{H}_{2} \mathrm{O}$ layer are inserted into each layer space of $\mathrm{TaS}_{2}$ for types I and II, respectively, while for types III and IV a single $\mathrm{H}_{2} \mathrm{O}$ layer inserted into every second and forth layer space of $\mathrm{TaS}_{2}$, respectively. Thus, respective types correspond to stage $1 / 2$, stage 1 , stage 2 and stage 4 compounds.

According to the proposed model, the observed amount of water of crystallization for each type is easily accounted for by assuming that each $\mathrm{H}_{2} \mathrm{O}$ monolayer consists of about $1 \mathrm{~mol} \mathrm{H}_{2} \mathrm{O}$ per $1 \mathrm{~mol} \mathrm{TaS}$. Similarly, the observed expansion of layer spacing $(\triangle c / 2)$ for each type can also be understood by the model if the $\mathrm{H}_{2} \mathrm{O}$ monolayer is about $3 \AA$ thick. Without this sort of stage compound model, it is difficult to explain why the water content and the layer expansion decreases on dehydration in the characteristic manner as observed.

It is to be noted that the proposed model is consistent with the appearance of supperlattice diffraction lines in the $\mathrm{X}$-ray diffraction patterns for types III and IV. As understood from Fig. 8 , all $\mathrm{TaS}_{2}$ layers in type $\mathrm{I}$ or $\mathbb{I}$ are arranged in a symmetric way to keep an identical distance between two neighboring $\mathrm{TaS}_{2}$ layers. This is not the case for types III and IV, where $\mathrm{TaS}_{2}$ layers are not spaced uniformly, the ob- 
served layer spacing, $c / 2$, is simply an average of actual spacings. This implies that types III and IV are interpreted as "superlattice" structures with respect to the stacking of $\mathrm{TaS}_{2}$ layers. This situation accounts for the appearance of (003) line for type III and (001/2) line for type IV in Fig. 5, which should be absent for a simple layer structure.

As mentioned above, the stage compounds model can be applied to the intercalation compounds very effectively. As compared with the stage compounds of graphite-alkali metal complexes, however, structural investigations to support this model are rather difficult because of poorer crystallinity of the compounds in this case. Further progress in this line of investiga- tion is highly desirable.

References :

1) e.g. F. Jellinek, J. Less-Common Metals 4, 9 (1962).

2) R.B. Somoano, Phys. Rev. Lett. 27, 402 (1971).

3) Y. Kanzaki, H. Konuma, and O. Matsumoto, J. Phys. Chem. Solids 41, 525 (1980).

4) F.R. Gamble, F.J. DiSalvo, R.A. Klemm, and T.H. Geball, Science 160, 568 (1970).

5) F.R. Gamble, J.H. Osiecki, and F.J. DiSalvo, $J$. Chem. Phys. 55, 3525 (1971).

6) G.V. Subba Rao, M.W. Shafer, and S.C. Tsang, $J$. Phys. Chem. 79, 553 (1975).

7) Y. Saito, M. Makino, N. Yamazoe, and T. Seiyama, Denki Kagaku 45, 746 (1977).

(Received Mar. 9, 1984; Accepted Jul. 24, 1984)

仓郃立 50 周年記念出版寨内

\author{
新しい電 気 化 学 \\ 電気化学協会編 A 5 判 288 ページ 定洒 2,500 円 (株) 培風館発行
}

本書は，電気化学協会創立 50 周年乳念事業の一つとして 編集委員会の奉仕により企画刊行されたもので，電気化学の基本的枠組 みと現在の動向が初学者にも概観できるようにまとめられた入阴的解説書であります。

エネルギー変換，電子材料，ライフサイエンスなどを軸にして，現在様相が一変しつつめるこの分野の新しい姿が豊富な図・写 真・イラストにより平易に解説されていま寸。

内容は次の通りで, 高校生の課外活動, 大学・高専のテキスト・参考書, 技術者・研究者の指導書として利用願えれ涬いです.

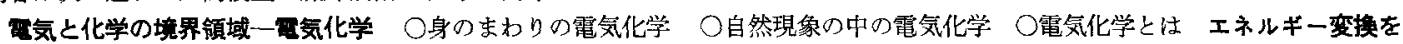
担う面気化学 ○現在のエネルギーと将来のエネルギー ○電気エネルギーに変換する ○太陽エネルギーの電気化学的な変換

資源利用を支える滥気化学 ○資源利用々電気化学 ○基礎素材をつくる電気化学 ○電気化学プロセスの新しい展開 生活の中 の電気化学 ○物を大切にする ○生活を大切にする ○生活を美しく ○表面に機能性を一電気化学の特技 ○生活を守る一保 守と環境保全 エレクトロニクスと雪気化学 ○電気上化学の接点一電子材料 ○エレクトロニクスの主役一半導体 ○半導体で

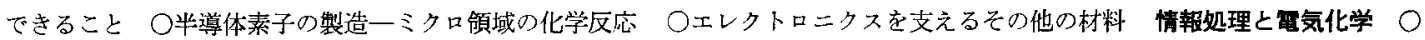
情報の変捘 ○情報の記録・表示とその材料 ライフサイェンスの未来をひらく西気化学 ○医療計浿に頁献する ○生体へのア プローチ ○人工臟器を支える ○生物電池 金気化学の未来 実験 ○ダニエル電池 ○酸素・水素燃料電池 ○太陽光による 水素発生光半導体電極 ○鉄の腐食を調べてみよう ○プラスチックにめっきする ○酸素センサーの製作 演習問題

论螎集委员会 委員長：平沢 椧, 委員 : 相沢益男, 青柿良一, 太田健一郎, 北沢宏一, 小浦延幸, 藤鸩 昭

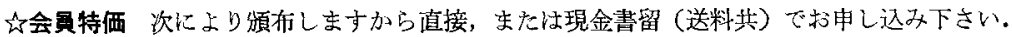

特 仾：1部 2,100 円 (送料 300 円. ただし送本多数の際はその実費)

期 間：昭和 60 年 1 月末までの閒

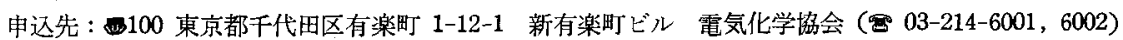

